
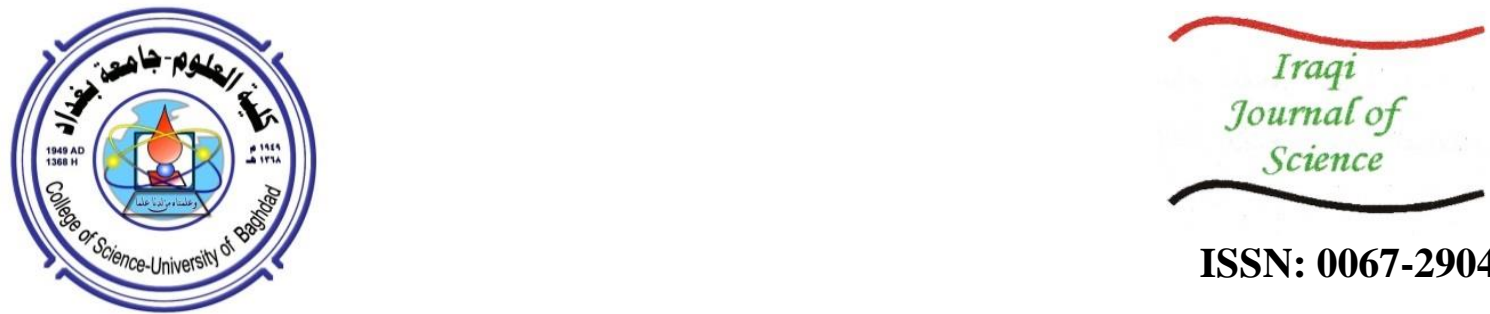

ISSN: 0067-2904

\title{
Use of Attributes on 3D Seismic Data for Studying Mishrif Formation in East Abu-Amoud Field, South-Eastern Iraq
}

\author{
Mohammed H. Al-Aaraji*1, Hussein H. Karim ${ }^{2}$ \\ ${ }^{1}$ Department of Geology, College of Science, University of Baghdad, Baghdad, Iraq. \\ ${ }^{2}$ Civil Engineering Department, University of Technology - Iraq, Baghdad, Iraq.
}

Received: $1 / 5 / 2021$

Accepted: 26/6/2021

\begin{abstract}
The seismic method depends on the nature of the reflected waves from the interfaces between layers, which in turn depends on the density and velocity of the layer, and this is called acoustic impedance. The seismic sections of the East AbuAmoud field that is located in Missan Province, south-eastern Iraq, were studied and interpreted for updating the structural picture of the major Mishrif Formation for the reservoir in the field. The Mishrif Formation is rich in petroleum in this area, with an area covering about $820 \mathrm{~km}^{2}$. The horizon was calibrated and defined on the seismic section with well logs data (well tops, check shot, sonic logs, and density logs) in the interpretation process to identify the upper and lower boundaries of the Formation. Seismic attributes were used to study the formation, including instantaneous phase attributes and relative acoustic impedance on time slice of 3D seismic data . Also, relative acoustic impedance was utilized to study the top of the Mishrif Formation. Based on these seismic attributes, karst features of the formation were identified. In addition, the nature of the lithology in the study area and the change in porosity were determined through the relative acoustic impedance The overlap of the top of the Mishrif Formation with the bottom of the Khasib Formation was determined because the Mishrif Formation is considered as an unconformity surface.
\end{abstract}

Keywards: MishrifFormation, seismic attributes, relative acoustic impedance, instantaneous phase, Abu-Amoud field.

\section{استخدام الملامح الزلزالية على بيانات زلزالية ثلاثية الابعاد لاراسة تكوين المشرف في حقل ابوعامود الشرقي، جنوب شرق العراق}

$$
\begin{aligned}
& \text { محمد حسين الأعرجي *1، حسين حميد كريم2 }
\end{aligned}
$$

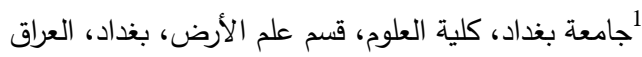

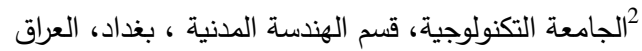

$$
\begin{aligned}
& \text { الخلاصة } \\
& \text { تعتد الطريقة الزلزالية على طبيعة الموجات الزلزالية المنعكسة من السطوح البينية بين الطبقات، والتي }
\end{aligned}
$$

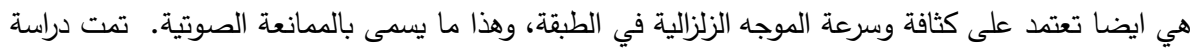

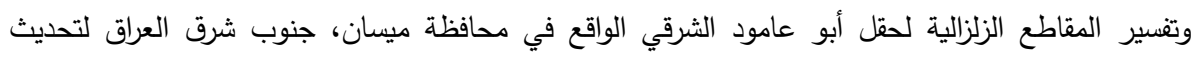

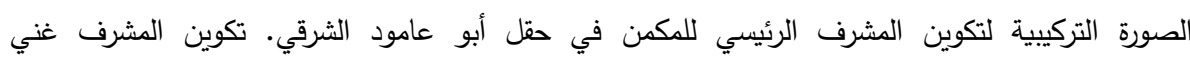

*Email: mohammadgeophysics@gmail.com 


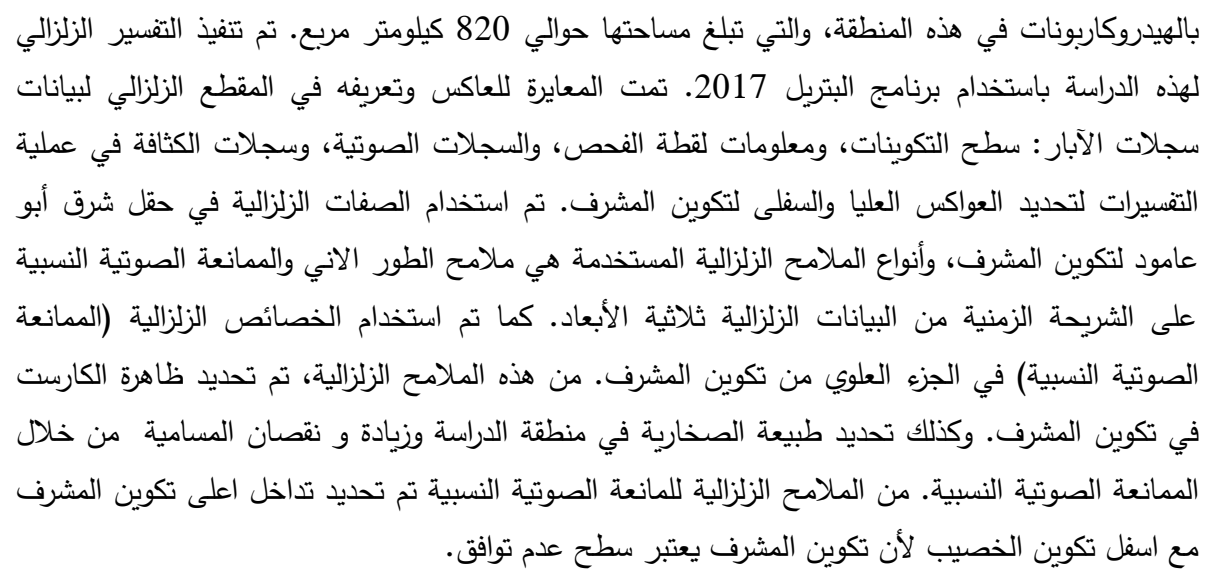

\section{Introduction}

The Mesopotamia Basin in central Iraq is of major importance to the petroleum production industry in the world. The basin constitutes a wide range of asymmetrical synclines, with different complexity levels, with other different structures [1]. East Abu-Amoud field is one of the most favorable hydrocarbon fields in the Mesopotamian basin. Mishrif Formation is an inhomogeneous carbonates Formations. It represents the most important petroleum-producing reservoir in southern Iraq. It was deposited during the Upper Cretaceous age within the main retrogressive depositional cycle "Cenomanian-Turonian stage" in southern Iraq. The Mishrif Formation is divided by unconformities into two large-scale regressive sequences that are particularly distinguished in the eastern Mesopotamian Basin. Several units of the reservoir are existing in both sequences. The west of the basin is predominated by the lower sequences, which have relatively little reservoir interval. The shallower water reservoir units in the east of the basin are thick, reflecting relatively high subsidence rates throughout the Cenomanian. Subsidence rates in the western part of the basin are lower, while the reservoir units are thinner and more bounded. The stratigraphic relations between the carbonates of the top of Mishrif and the top of Rumaila formations in central Iraq are complex. The carbonates were deposited in either an outer shell or basin, setting the Rumaila Formation, or a shallower water inner-shelf, setting the Mishrif Formation. The Rumaila Formation units constitute finegrained marly and chalky limestones; they alternate with the thicker units of the Mishrif Formation, which in general, are composed of coarse-grained carbonate.

The role of the seismic reflections method in the petroleum prospecting is to provide the most precise pictorial representations of the subsurface and its geological structures. This method provides contour maps of seismic data, velocity, and time to identify the traps of structural, stratigraphy, and seismic facies. This leads to a stratigraphic geometry interpretation in terms of environmental deposition paleogeography, in addition to the sedimentary analysis of the basin under study [2].

Reflection coefficients, or logs, of successive interfaces between the layers are well known. These logs are derived from the acoustic impedance log. The function of reflectivity is the property of layers that we are looking for [3].

Karim and Al-Aaraji (2021) [4] carried out a study concerning the stratigraphic and structural seismic interpretation in East Abu-Amoud Field, Missan Province, south-eastern Iraq. The study aimed to update the structural picture of the Yammama oil Formation in the field.

The main goal of the present manuscript is to study the structural interpretation of seismic data of Mishrif Formation in East Abu-Amoud Field, southeastern Iraq.

\section{Area of the study}

The results of the gravity survey (achieved by the BPC, Basra Petroleum Company) and the aeromagnetic survey (achieved by the CGG, the Geophysical French Company) hold the potential to implement other detailed surveys, since the structural setting shows the 
hydrocarbon potential areas of southern Iraqi, including the study area [5]. East Abu-Amoud field is located in southern Iraq within the administrative boundaries of Missan Province. Table 1 presents the coordinates of the East Abu- Amoud field. It is about $45 \mathrm{~km}$ west of the Amara district and $40 \mathrm{~km}$ southeast of Abu-Amoud field (Figure 1). The area is distinguished by its flattened terrain within a flattened alluvial sediment region. It is surrounded on the eastern side by the marshland region, and it was affected by the high levels of water during the flood age [6].

Table 1-Coordinates of East Abu- Amoud field.

\begin{tabular}{|c|c|c|}
\hline \multirow{2}{*}{ Points } & \multicolumn{2}{|c|}{ Coordinates } \\
\cline { 2 - 3 } & 631912.78 & $\mathrm{y}$ \\
\hline $\mathrm{A}$ & 624946.03 & 3535098.82 \\
\hline $\mathrm{B}$ & 674111.80 & 3520230.01 \\
\hline $\mathrm{D}$ & 682934.94 & 3499091.72 \\
\hline
\end{tabular}

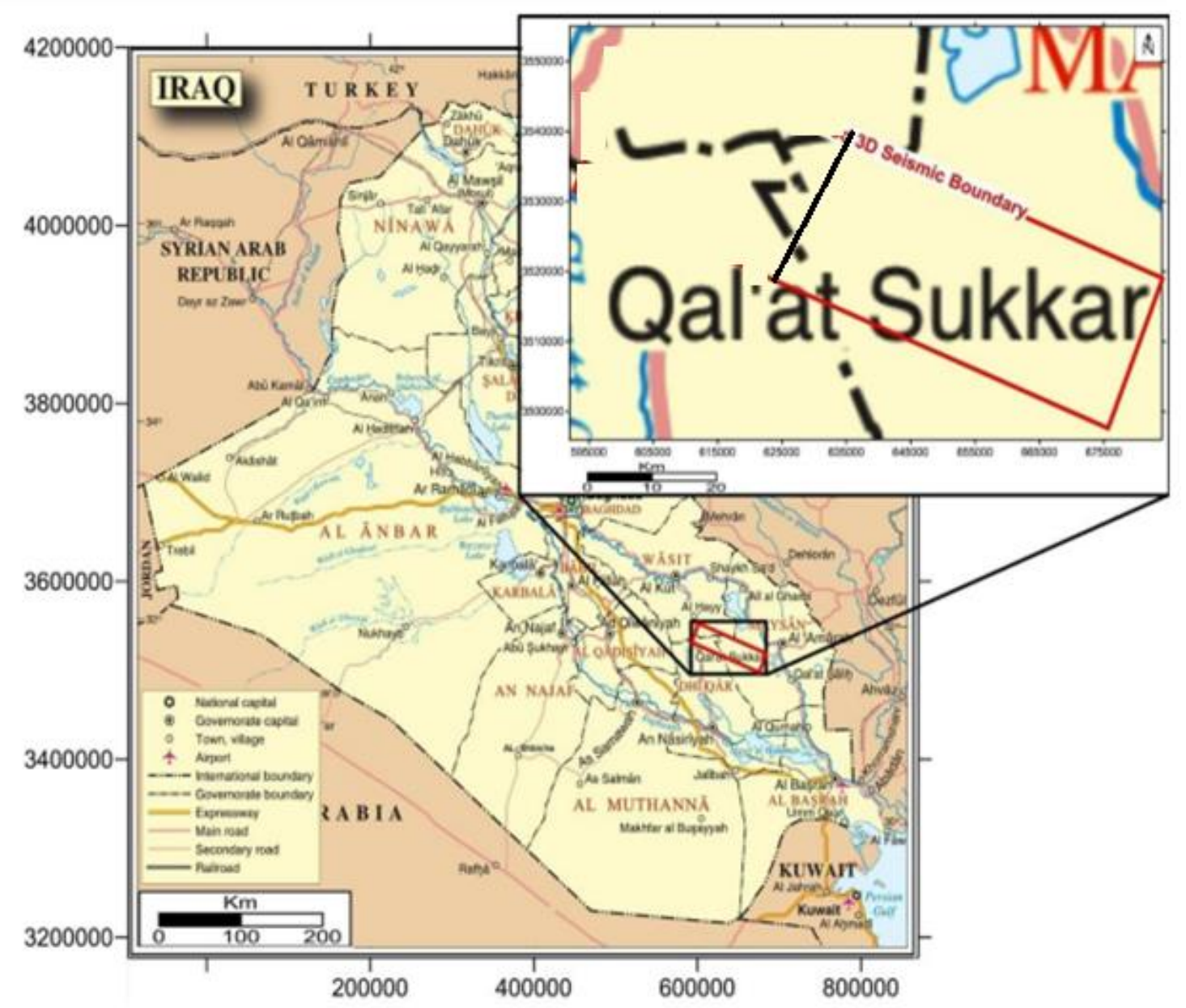

Figure 1- Location map of the study area.

\section{Geological setting}

Both tectonic and isostatic forces are controlling depositions of the Mishrif Formation in Iraq. According to the stratigraphic sequence of the upper Cretaceous age in Iraq [6], the Mishrif Formation belongs to the late Cenomanian-early Turonian Super-sequence. In addition, it is equivalent to the topmost portion of the tectonic stratigraphic Megasequence [7], which was deposited on a passive margin setting. The study region is located in the Mesopotamian structural zone, which is subdivided into the Zubair, Tigris, and Euphrates 
tectonic subzones [8]. The stratigraphic profile of this subdivision shows the evident thickness of the Mishrif Formation along the Tigris subzone, which indicates high subsidence rates. Each one of these subzones is distinguished by higher and lower structures with changes in trends, which were formed by the north-eastern Tethyan margin deformation of the Arabian Plate in the Cenomanian-Early Turonian ages as shown in Figure 2 [9]. Several structures in southern Iraq are the consequence of salt diapirism, as specified by the existence of negative gravity residuals below some supergiant oil field structures, like Zubair, Rumaila, and Nahr Umr $[6,8,10,11]$. Some of these structures began rising during the Early Jurassic $[12,13]$.

\section{Seismic wave's reflection}

Seismic energy propagation in the Earth is very complex. Figure 3 shows several factors that are related to geology and acquisition. The aim is to relate the seismic amplitude of rock property contrast through reflection boundary. However, there are many other factors aside from geology that also influence amplitude. Some of these are related with the equipment used for the survey; these include variability of source strength and coupling from shot to shot, variability of sensitivity and coupling from one receiver to another, the directivity of the receivers array "more sensitive at some incidence angles than others" and the low accuracy of the recording tools [14].

Seismic of marine has the quality which sources and receivers are very repeatable in their distinguishes. This is not proper to land surveys, where the coupling of source and receivers to the land may be quite variable from one shot to another, depending on surface conditions. Yet, these effects can be evaluated by the seismic processor. Several amplitude effects are features of the subsurface that are of little direct interest and, ideally, would be removed from the data during processing; these involve divergence effects, multiples, scattering, reflection curvature and rugosity, and general superimposed noise. Depending on the individual data set, removing these may be quite difficult without damaging the amplitude response of interest. The processor obviously faces strong challenges to alleviate the effects of unwanted acquisition and transmission factors and enhance the geological content of the data [14].

$\mathrm{RC}=$ Reflection coefficient

$$
R C=\frac{(Z 2-Z 1)}{Z 2+Z 1}
$$

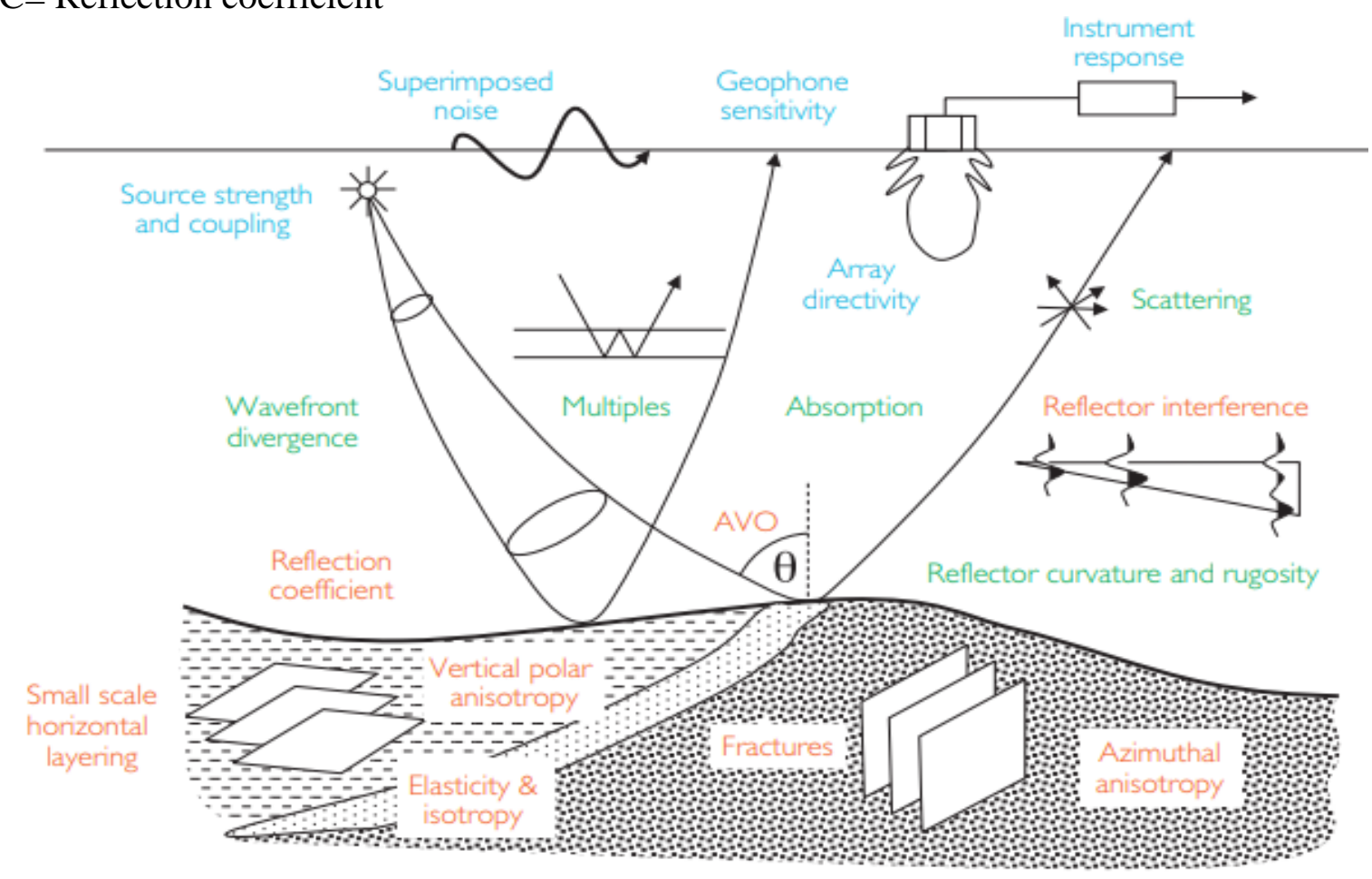

Figure 2-Factors affecting seismic amplitude [14]. 


\section{Seismic Attributes}

The instantaneous phase is a good indicator of faults, pinch-outs, continuities, layer interfaces, changes of lithologies, and regions of onlap patterns. The attribute provides an amplitude independent presentation which is especially helpful to reveal the continuity of reflectors that vary widely in their amplitude. The instantaneous phase is commonly used to find continuity of weak events and to characterize small faults and dipping events. The attribute tends to enhance weak intra-reservoir events but also enhances noise [15].

The relative acoustic impedance attribute shows the apparent acoustic contrast, which indicates changes in lithologies, unconformity, and discontinuities. Relative acoustic impedance can also indicate porosity or fluid content in the reservoir [15]. Instantaneous frequency is calculated from the temporal rate of change of the instantaneous phase, which is a derivative of time. Instantaneous frequency is often utilized to assess seismic attenuation. Oil and gas reservoirs usually cause a drop-off of high-frequency components. Instantaneous frequency helps to measure the cyclicity of geological intervals and can be helpful for crosscorrelation across faults. It could as well distinguish contacts between gas and water or gas and oil. Instantaneous frequency tends to be unstable in the existence of noise and is sometimes difficult to interpret [15].

The present study aims at using seismic attributes on the seismic sections and on the time map of the top Mishrif Formation to identify the features that affect the East Abu Amoud field (the Cenomanian - early Turronian).

\section{Methodology}

A procedure with several steps was followed to achieve the goals of studying and updating the subsurface picture of Mishrif Formation, which is the formation of major interest in this study. Seismic data were first acquired and a synthetic seismogram was then created from these data (Figure 4). Next, a time map of the top of Mishrif Formation was drawn, in which the seismic attributes were identified and analyzed. 


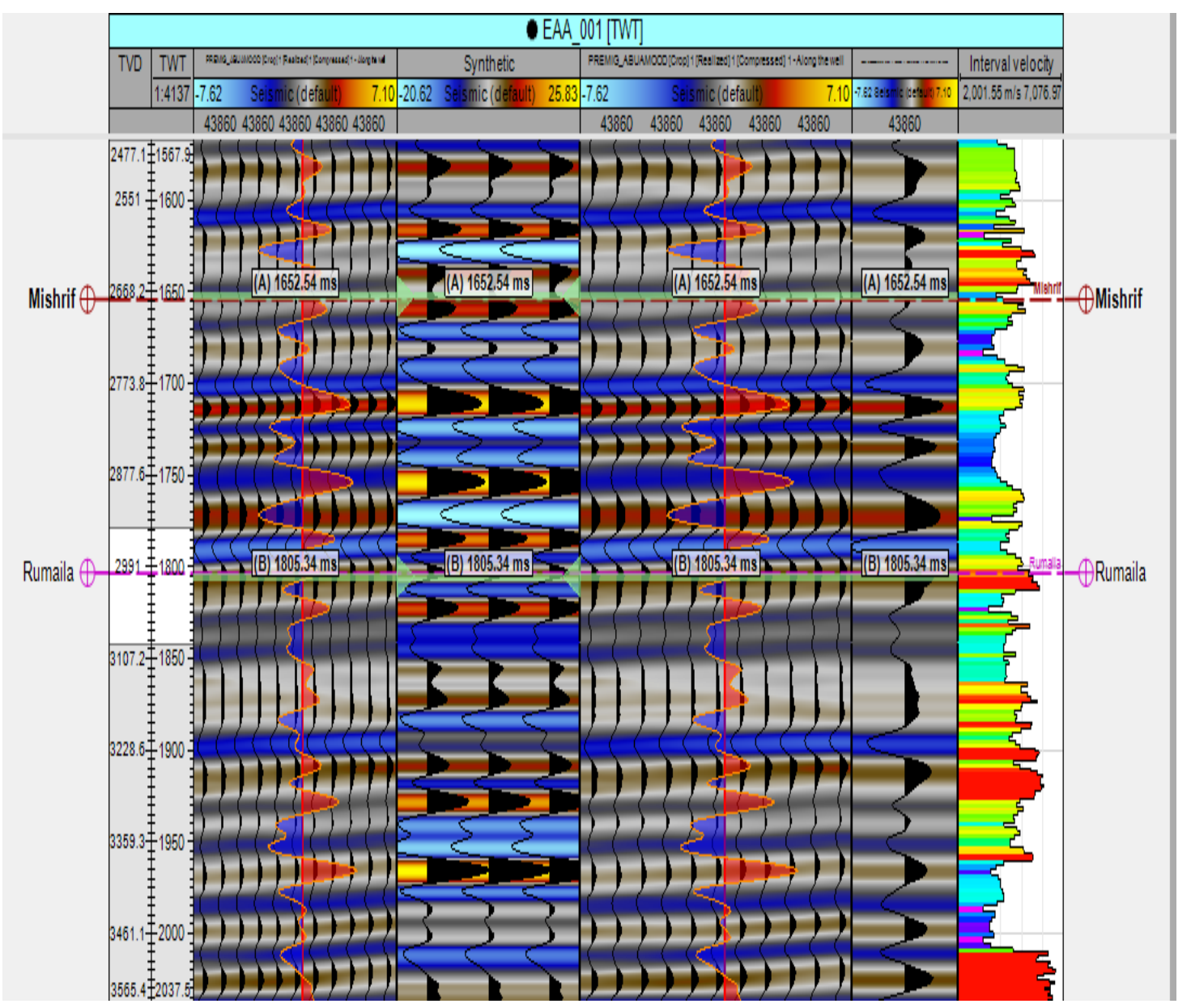

Figure 3- Synthetic seismogram showing the location time of Mishrif Formation in East AbuAmoud (EAA) field.

\section{Results}

The seismic attributes showed a clear karst feature, which is associated with soluble rock types such as limestone. Also, color change indicates that the sedimentation is changing in lithology. These changes were caused by the changes in sea level during the Cenomanian stage, which caused sedimentation changes, as shown in Figure 5.

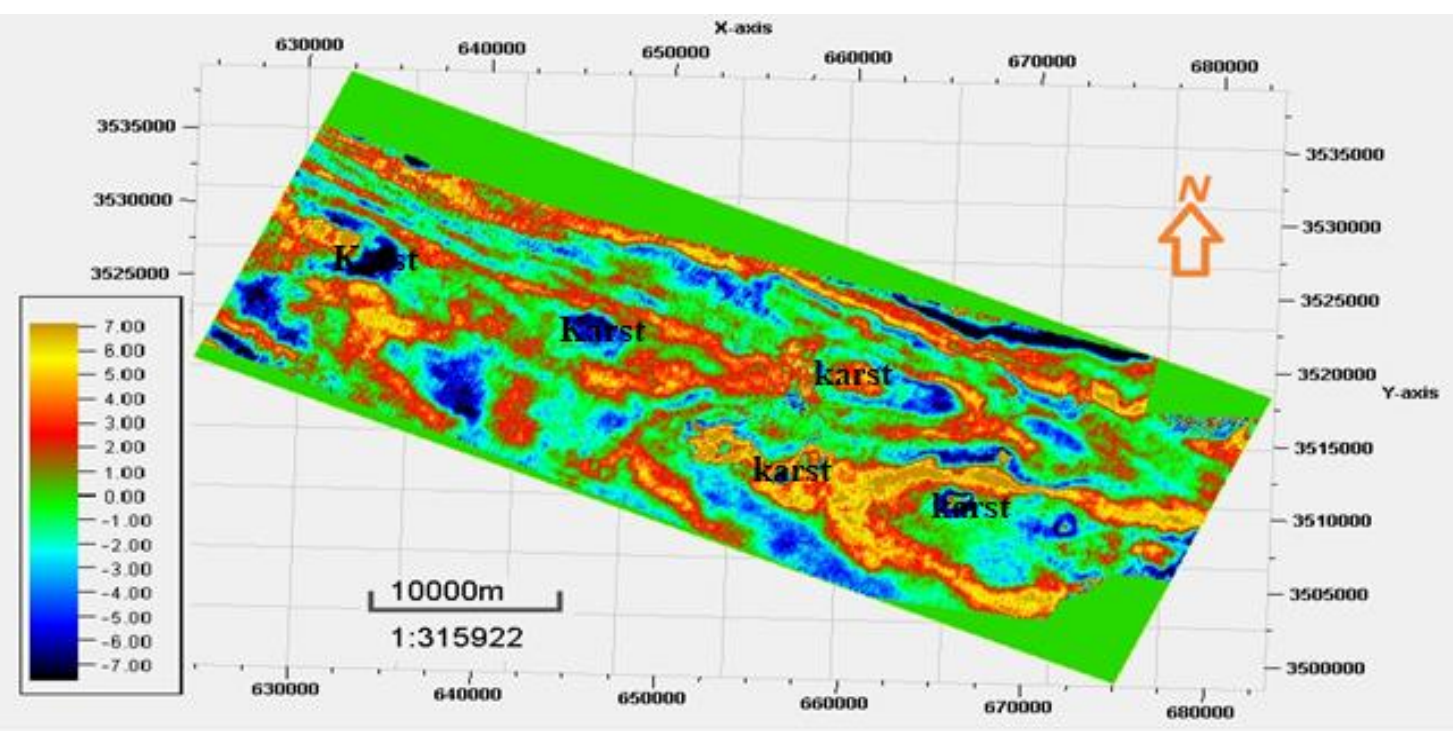

Figure 4- Acoustic impedance attribute on time slice at time $1670 \mathrm{~ms}$. 
The surface attribute of the relative acoustic impedance of the top of Mishrif Formation (Mishrif A), where the Mishrif Formation is peak reflector, is demonstrated in red color in Figure 7. Some other areas of Mishrif Formation appear as a trough (blue color). The main reason for the occurrence of this phenomenon is the intrusion of the bottom of the Khasib Formation with the top of the Mishrif Formation. This means that the Mishrif Formation remained exposed for very long periods and that erosion occurred at the top of the Mishrif Formation during the period at which the sea receded. In addition, when the sea flooded again, some deposits from the bottom of Khasib Formation were deposited in the eroded areas on the top of Mishrif Formation. The dark red spots express the dim spots, as shown in Figure 6, this indicates that hydrocarbons may be present.

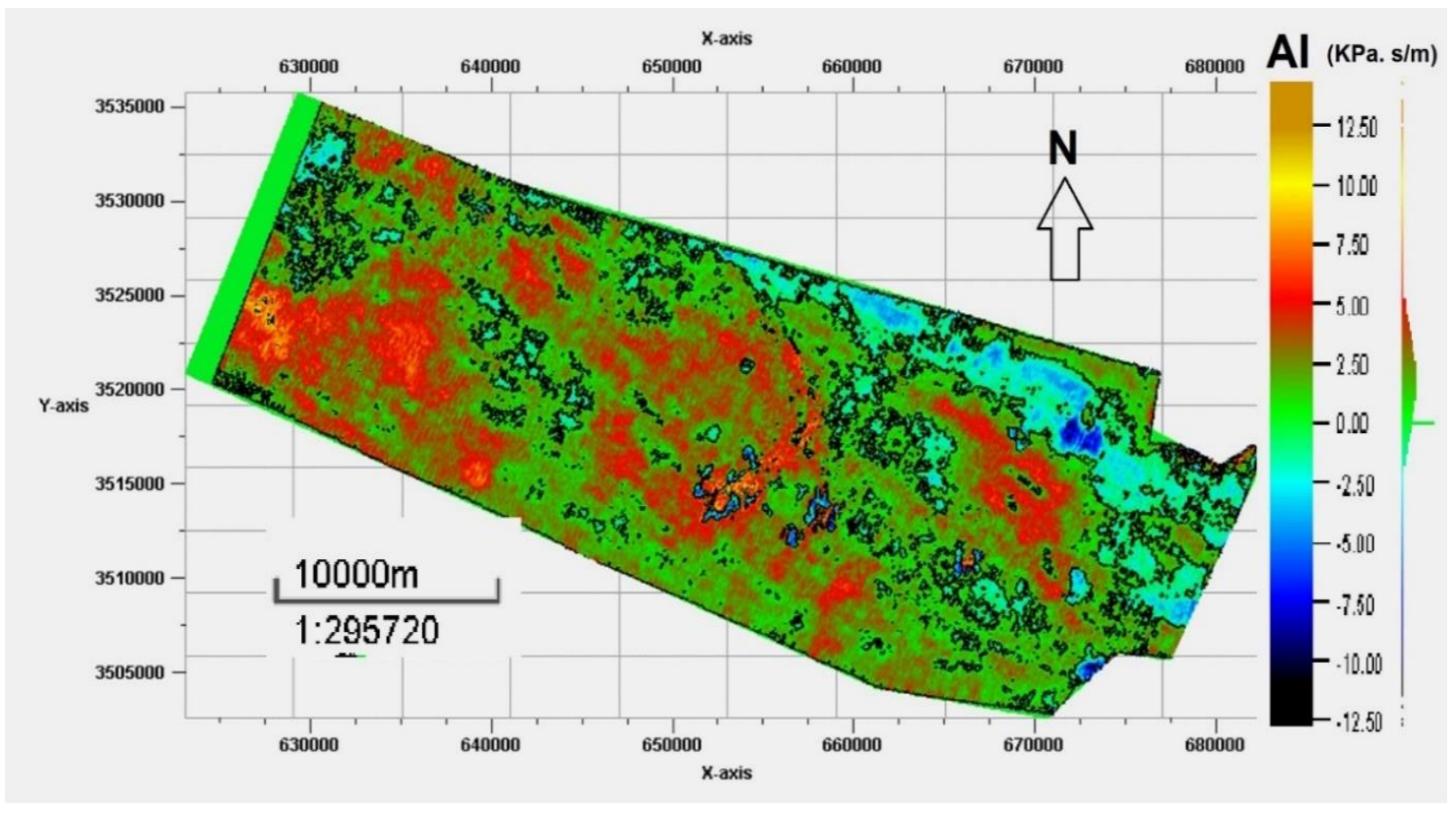

Figure 5- Surface attribute of relative acoustic impedance of top of Mishrif Formation.

The sequence of Ahmadi, Rumaila, and Mishrif Formations belongs to the Cenomanian-early Turonian age. The intrashelf basin was developed during the Cenomanian age by the domination of shallow water with carbonate ramps. That event occurred due to the growth of Oman-Zagros margin bulge, where the Mishrif Formation was deposited above the high barrier or on the separate platform. The Mishrif Formation is constituted of a shallow upward cycle associated with the continuance of the compression tectonics system. This has led to the appearance of the unconform surface at the top of the Mishrif Formation, which is overlaid by the Khasib Formation.

\section{Conclusions}

Based on the study of surface attributes, it is noticed that the top of the Mishrif Formationit was exposed to erosion, which indicates that this Formation represents the end of a sedimentation cycle, being exposed for a long period of time. We also observed the presence of karst features in the study area. In addition, the presence of dim spots indicated the presence of hydrocarbons in the East Abu Amoud field.

\section{References}

[1] Ditmar, V., Afanasiev, J., Brioussov, B. and Shaban, S., Geological Conditions and Hydrocarbon prospects of the Republic of Iraq. Vol. II, Southern part. Techno Export Report, INOC Lib., Baghdad, 14p, 1973. 
[2] Ali, k.k, Al-Sharaa, H.G and Rasheed, H A., "3D Seismic Structural and Stratigraphy Study of Shuaiba Formation in Kumait Oil Field-Southern Iraq", Iraqi Journal of Science, pp. 8, 2018.

[3] Khorshid, Z.S, Alki, D.H and Zaid, M.A., "Subsurface Investigation of Merjan oil field Depending on 3D Seismic Reflection Central Iraq", Iraqi Journal of Science, pp. 2457-2469, 2016.

[4] Karim, H.H. and Al-Aaraji, M.H., "Stratigraphic and structural seismic interpretation of Yammama Formation in East Abu-Amoud Field-Missan Province, Southeastern Iraq". Solid State Technology, vol. 64, Issue 2, pp. 1642-1649, 2021.

[5] Oil Exploration Company, Exploration geologic study for Al-Rafidain-Garraf axis, 15p., 2010

[6] Oil Exploration Company, Final field report of 3D seismic survey for Abo Amood field, internal report, Ministry of oil, unpublished study 12p., 2013.

[7] Sharland, P.R., Archer, R., Casey, D.M., Davies, R.B., Hall, S.H., Heward, A.P., Horbury, A.D. and Simmons, M.D., Arabian Plate Sequence Stratigraphy. Geo Arabia Special Publication 2, Gulf PetroLink, Bahrain, 371p., 2001.

[8] Buday, T. and Jassim, S., The Regional Geology of Iraq: Tectonics, Magmatism, and Metamorphism. In: Kassab, I.I. and Abbas, M.J., Eds., Geology of Iraq, Geologic Survey, Baghdad, 445p., 1987.

[9] Karim, H.H., "Qualitative interpretation of Basrah aeromagnetic map", J. Geol. Soc. Iraq. vol. 22, no. 2, pp. 1-8, 1989.

[10] Karim, H.H., "General properties and patterns of the gravity field of Basrah area, SE Iraq". Iraqi Geol. J., vol. 26, no. 1, p. 150-178, 1993.

[11] Jassim, S.Z. and Goff, J.C., Geology of Iraq, Czech Republic, Brno, 341p., 2006.

[12] Sadooni, F.N. and Aqrawi, A.A.M., "Cretaceous sequence stratigraphy and petroleum potential of the Mesopotamian Basin, Iraq". In Scott, B and Al-Sharhan, A.S. (Eds.), Middle East Models of Jurassic/Cretaceous Carbonate Systems. SEPM Special Publication, vol. 69, pp. 315-334, 2000.

[13] Aqrawi, A. A. M., Goff, J. C., Horbury, A. D., and Sadooni, F. N., The petroleum geology of Iraq. Cambrian Printers, Aberystwyth, 424p, 2010.

[14] Simm, R, Bacon, M.., Seismic amplitude an interpretaer's handbook. Cambridge, United Kingdom: Cambridge University Press, 283p, 2014.

[15] Brances, A. E., Handbook of Post-Stack Seismic Attributes, Society of Exploration Geophysicists, 269 p., 2016. 